\title{
Despre traducerea propriu-zisă a toponimelor în traduceri românești de la începutul secolului al XIX-lea ${ }^{\dagger}$
}

\author{
Dinu Moscal ${ }^{*}$ \\ Institutul de Filologie Română „A. Philippide”, Str. Th. Codrescu 2, 700481 Iași, România
}

Despre articol
Istoric:
Primit 19 iulie 2018
Acceptat 20 august 2018
Publicat 7 octombrie 2018
Cuvinte-cheie:
nume propriu
toponim
traducere
limba română
secolul al XIX-lea

\begin{abstract}
Rezumat
Traducerea unor toponime încă neintrate în limba română la începutul secolului al XIX-lea a constituit o adevărată provocare pentru traducătorii din epocă. Un prim aspect îl constituie statutul special al acestora ca nume proprii și opțiunile de traducere posibile, care nu puteau fi corelate cu o tradiție. Un al doilea aspect este stadiul încă precar al terminologiei geografice, reflectat în variația terminologică pentru acelaşi concept și în lipsa de afinitate semantică, fie reală, fie numai în raport cu terminologia actuală. Obiectivul principal în această scurtă analiză îl constituie primul aspect menționat. Pentru a discuta aceste aspecte, a fost necesară o succintă precizare a conceptului de traducere la nivelul numelui propriu și a distincției între nume proprii netraductibile şi nume proprii traductibile sau parțial traductibile. În cazul celor din urmă am identificat factorii favorizanți pentru opțiunea de a traduce sau pentru opțiunea de a nu traduce ceea ce este traductibil. Corpusul de referință reflectă un stadiu incipient al traducerii toponimelor traductibile sau parțial traductibile în limba română, stadiu în care traducătorul este liber să interpreteze traductibilitatea. În raport cu variantele care s-au impus în norma actuală, alegerile diferite de la un traducător la altul sau chiar la acelaşi traducător, în special opțiunea de a nu traduce toponime care astăzi se traduc în toate limbile de circulație, constituie un argument al lipsei importanței semnificației lingvistice a numelui propriu (propriu-zis, semnificația lexicală a etimonului) în funcționarea sa și, implicit, rolul acestei nonfuncționalități în identificarea statutului lingvistic al numelui propriu. Oscilarea între traducerea și adaptarea formală a unui toponim traductibil în cazul anumitor tipuri de toponime și particularitățile lingvistice proprii respectivei epoci reprezintă o fațetă a istoriei limbii române la nivel onomastic.
\end{abstract}

\section{Introducere}

Problematica traducerii numelor proprii este la fel de complexă ca și statutul numelui propriu ca semn lingvistic și se caracterizaează prin aceeași eterogeneitate privind perspectivele și metodele de abordare. Dificultăţile întîmpinate în definirea numelui propriu, dintre care se detașează ca importanță problema semanticităţii sale, fac ca și rezultatele analizei tratamentului numelui propriu în traduceri să nu fie convergente la nivel general. Afirmația lui Vaxelaire (2005, p. 63) cu privire la statutul lingvistic al numelui propriu este valabilă în mare măsură și în ceea ce privește traducerea acestuia: „Il est courant de lire tout et son contraire sur le nom propre, on glose beaucoup à son sujet sans pouvoir pour autant prendre le temps de définir ce qu'il est exactement".

În literatura de specialitate, eclectismul abordării procedeelor de trecere a numelui propriu dintr-o limbă în alta este favorizat în special de lipsa unei identități clare a acestuia ca entitate lingvistică, mai ales în privința naturii conținutului său: ,the only words one does use as names in the logical sense are words like «this» or «that»" (Gardiner, 1957, p. 59, idee preluată ca atare în Kuryłowicz, 1980, p. 6); ,il peut

${ }^{\dagger} \mathrm{O}$ versiune anterioară a acestui text a fost prezentată sub formă de comunicare la simpozionul „Toponimia între istorie, geografie și lingvistică”, Iași, 10 mai 2018.

*Adresă de corespondență: dinu.moscal@gmail.com. 
y avoir des sous-catégories fonctionnelles, comme le nom propre à l'intérieur des pronoms-substantifs" (Hjelmslev, 1971, p. 207); „le nom propre est [...] fondamentalement un référent” (Clarinval, 1967, p. 34); „en effet, le nom propre est un nom, mais son fonctionnement morpho-syntaxique, sémantique et pragmatique le rapproche des déictiques, des pronoms personnels par exemple" (Molino, 1982, p. 19). Lipsa unui conținut semantic sau, conform terminologiei folosite de logicieni, a unui „sens”, concordă cu punctul de vedere al unor onomasticieni în privința traductibilităţii numelor proprii, de exemplu: „ne se traduisent presque jamais” (Mańczak, 1968, p. 207), „they are untranslatable” (Algeo, 1973, p. 63).

Dacă se are în vedere că funcționarea numelui propriu nu se bazează pe raportul de semnificare (aşa cum este cazul pentru numele comun), ci pe raportul de denominare (echivalent cu raportul de desemnare de la nivelul numelui comun), și că raportul de semnificare se activează doar la nivel de metalimbaj (demersul etimologic, fie acesta științific sau nu), cunoașterea semnificației numelui propriu nu are relevanță în funcționarea acestuia. Evidențiind funcția denominativă a numelui propriu, Kleiber (1981, p. 503) consideră că „toute modification aboutit, non à une traduction d'un nom propre, mais à un nouveau nom propre”. Astfel, dintr-o perspectivă funcțională, traducerea numelor proprii este mai curînd negată decît analizată. Este însă evident că numele proprii nu rămîn intacte în trecerea lor dintr-o limbă în alta, o opțiune fiind chiar traducerea propriu-zisă, iar acest lucru a condus la diverse analize ale procedeelor utilizate. Și în cazul numelor proprii se traduce semnificația lexicală, însă aceasta nu are aceeași poziție în cadrul numelui propriu ca în interiorul numelui comun. În plus, semnificația lexicală nu are un rol în funcționarea numelui propriu, fiind mai degrabă un element de substrat. În cazul numelui propriu, semnificația lexicală este similară semnificației etimologice de la nivelul lexicului.

Numele proprii Coasta de Fildeş, Ivory Coast, Elfenbeinküste, Costa de Marfil sau Marele Lac Sărat, Grad Lac Salée, Großer Salzsee, El Gran Lago Salado sînt traduceri ale numelor proprii Côte d'Ivoire și The Great Salt Lake. Însă unele nume proprii nu pot fi traduse, în timp ce altele pot fi traduse, iar dintre acestea din urmă unele se traduc, iar altele nu se traduc. Acest fapt arată că problema reală în privinţa traducerii numelor proprii nu este dacă se traduc sau nu, ci de ce unele dintre numele traductibile se traduc, iar altele nu. Altfel spus, înainte de a aborda problema traducerii lor, ar fi necesară abordarea problemei traductibilităţii lor. Un pas intermediar ar fi aflarea unui răspuns la întrebarea privitoare la motivul pentru care unele nume proprii traductibile se traduc (vezi exemplele de mai sus), iar altele nu se traduc (Salt Lake City, Rio Grande, Mont Blanc etc.).

O problemă importantă în ceea ce privește traducerea numelui propriu o constituie tratarea nediferențiată la nivel general a titlurilor și a numelor proprii (care pot funcționa ca titlu sau ca parte dintr-un titlu). Astfel, Ansichten eines Clowns este un titlu care nu conține vreun nume propriu, North Atlantic Treaty Organization este un titlu care conține un nume propriu (toponimul Atlantic), Anna Karenina este un titlu care constă dintr-un nume propriu intraductibil; titlurile pot fi traduse total (primul exemplu), parțial (al doilea exemplu) sau nu pot fi traduse (al treilea exemplu). Pe de altă parte, unele sintagme denominative (nume proprii plurilexicale) se traduc parțial, de exemplu: lat. Mare Mediterraneum fr. Mer Méditerranée, rom. Marea Mediterană, engl. Mediterarranean Sea (dar germ. Mittelländische Meer sau Mittelmeer); engl. United States of America - fr. Étas-Unis d'Amérique, rom. Statele Unite ale Americii etc. Prin urmare, o tipologie a traducerii numelor proprii, deci și a toponimelor, ar trebui să aibă în vedere criteriul traductibilității și să deceleze întîi caracteristicile care fac un nume propriu intraductibil sau traductibil, după care pe cele care fac ca numele proprii traductibile (sau parțial traductibile în cazul sintagmelor denominative) să fie traduse, parțial traduse sau netraduse.

\section{Traducerea propriu-zisă}

În lucrările dedicate traducerii numelui propriu, termenul traducere este folosit cu două accepții: ca termen generic, prin care se înțelege orice procedeu de trecere a numelui propriu dintr-o limbă în alta (cf. Moya, 2001; Grass, 2002; Ballard, 2011), și ca termen specific, prin care se înţeleg numai acele procedee de traducere cu implicații semantice. Ca termen generic, traducerea numelor proprii cuprinde procedee de 
natură formală (adaptarea grafică, fonetică și morfologică) și semantică (diferitele tipuri de traducere și substituirea), la care se adaugă și împrumutul, care presupune, în principiu, păstrarea numelui propriu în forma din limba sursă (pentru detalii, vezi Gînsac et al., 2017, p. 61-66).

Procedeele subsumate termenului generic traducere variază de la un autor la altul. Redăm strict pentru ilustrare tipologia propusă de Grass (2002, p. 115-122): calc (Strait of Dover = Strasse von Dover = Pas de Calais), traducere literală (NATO North Atlantic Treaty Organization= OTAN Organisation du Traité de l'Atlantique Nord = Nordatlantikpakt-Organisation), transpunere (das Vorparlament = le Parlament préparatoire), modulare ([Sieg bei] Königgrätz $=$ [Défaite de] Sadowa), adaptare (Ansichten eines Clowns $(\mathrm{H}$. Böll) $\approx$ La Grimace), traducere explicativă (Studienstiftung des Deutschen Volkes - „organisation allemande qui accorde des bourses aux meilleurs étudiants allemands”), echivalență totală (Versailler Vertrag - Traité de Versailles). Este însă evident că tipologia lui Grass este foarte apropiată de teoriile despre traducere în general, ceea ce autorul însuși evidențiază, indicînd sursele (Malblanc, 1968 și Vinay \& Darbelnet, 1958) și transferul tipologiei procedeelor de traducere: „Malgré leur âge, ces ouvrages proposent une terminologie simple et toujours utilisée" (Grass, 2002, p. 114). Nici alți autori (Ballard, 2011; Moya, 2001) care propun o tipologie a traducerii numelor proprii nu aduc o contribuție cu un rol determinant în acest domeniu.

Traducerea propriu-zisă a numelui propriu este în realitate traducerea semnificaţiei etimologice a termenilor transparenți semantic constitutivi. Deși în multe cazuri semnificația etimologică (cea a apelativului cu funcție toponimică, ca parte a unei sintagme denominative) este o mărturie a raportului de desemnare de la baza creației sintagmei denominative, această semnificaţie nu face decît să confirme o „dreaptă denumire” a unei anumite realități, dar fără să aibă și rolul de a o identifica, tocmai aceasta din urmă fiind trăsătura distinctivă a unui nume propriu. Astfel, dacă, de exemplu, am avea în limba română traducerea Oraşul nou (pentru oricare dintre toponimele de mai jos), semnificația etimologică indică în mod clar un oiconim (se referă la un oraș), adică indică doar categoria onomastică, dar nu este la fel de clar în ceea ce privește raportul de desemnare (care oraș). Însă rus. Novgorod, fr. Villeneuve / Neuville, germ. Neustadt, sp. Nueva Ciudad / Ciudad Nueva restrîng aria de posibilități a desemnării prin trimiterea la un spaţiu în care se vorbește sau s-a vorbit limba respectivă. Desigur, Novgorod se poate referi la oraşul actual sau la fosta republică medievală, Villeneuve / Neuville și Neustadt desemnează fiecare mai multe localităţi din spaţiul (fost) germanofon sau (fost) francofon. Nueva Ciudad şi Ciudad Nueva sînt nume de cartier în mai multe orașe din America Latină. Însă Nueva Ciudad poate fi și un nume metaforic, adică să nu fie oiconim. Villeneuve și Neuville sînt oiconime, dar sînt și antroponime, trecerea dintr-o categorie onomastică în alta fiind un fenomen natural la nivel general. În mod evident, traducerea propriuzisă este o opțiune în cazul numelor „descriptive”, în funcție de semnificația apelativului categorial din sintagma denominativă. Apelativele categoriale cu semnificaţia 'oraș,' 'rîu', 'munte' etc. formează adesea sintagme denominative împreună cu un adjectiv sau cu un nume opac. Dacă există o corespondență între semnificația apelativului intrat într-o sintagmă denominativă (devenită semnificaţie etimologică la nivel de nume propriu), atunci traducerea este o opțiune. În astfel de cazuri trebuie observat tratamentul sintagmelor denominative complet traductibile, așa cum sînt exemplele de mai sus, și tratamentul sintagmelor denominative parțial traductibile, de tipul Marea Azov, Munții Carpați etc.

Pornind de la considerațiile de mai sus, ne propunem să urmărim problema traducerii propriu-zise a toponimelor în cîteva traduceri românești ale unor texte geografice și istorice de la începutul secolului al XIX-lea (vezi Bibliografia, secțiunea Surse; pentru detalii privind textele, vezi Gînsac et al., 2017, p. 15 ș.u.). Traducerea propriu-zisă desemnează în prezentul demers orice tip de traducere semantică, singura diferențiere fiind cea dintre traducerea integrală și cea parțială. Analiza toponimelor se va limita la traducerea toponimelor traductibile sau a elementelor traductibile dintr-o sintagmă toponimică, indiferent de modul în care poate fi calificată traducerea (traducere literală, calc etc.). Calificarea traducerii este în realitate o problemă secundară, doar cu rol de clasificare. Importantă este decelarea factorilor favorizanți pentru traducerea, respectiv netraducerea, toponimelor traductibile sau a elementelor traductibile dintr-o sintagmă toponimică.

Traducerea propriu-zisă a numelor proprii în general reprezintă o opțiune posibilă în cazul numelor 
proprii traductibile sau al celor parțial traductibile (elemente dintr-o sintagmă denominativă). Pe baza exemplelor discutate se pot face observații despre alegerea traducătorilor de a traduce toponimele traductibile sau elementele traductibile din sintagmele toponimice, precum și în privința instituirii unei „norme tradiționale” prin selectarea unei anumite soluții în detrimentul alteia. Identificarea unor situații tipice în care numele traductibile sau elementele traductibile sînt traduse și, de asemenea, identificarea posibilelor motivații ale opțiunii de a traduce un nume sau un element dintr-o sintagmă denominativă contribuie la stabilirea cîtorva trăsături ale istoricului transpunerii toponimelor în limba română, oferind totodată și unele indicii privind posibilele motivații ale opțiunii de a traduce sau nu un nume propriu traductibil sau elementul/ elementele traductibil(e) dintr-o sintagmă denominativă. Calitatea și specificul traducerii în sine nu este o problemă specifică traducerii numelor proprii, ci este o problemă de traducere la nivel general, motiv pentru care nu li se va acorda o atenție specială.

\section{Traduceri propriu-zise ale toponimelor în română la începutul sec. al XIX-lea}

\subsection{Traduceri integrale}

Traducerea integrală este posibilă numai în cazul toponimelor compuse sau a sintagmelor transparente semantic, adică în cazul (cvasi)omonimei între elementele componente din sintagma denominativă și apelativele de origine corespondente.

În textele traduse în perioada avută în vedere (sfîrșitul secolului al XVIII-lea și începutul secolului al XIX-lea), sintagmele al căror determinat este un termen geografic (care indică categoria toponimică), iar determinantul este un calificativ sau un circumstanțial, sînt, în general, traduse. Acest fapt corespunde parțial normei actuale, cu deosebirea că toponimele actuale nu păstrează vechea terminologie și nu se admit variante, deoarece sînt standardizate:

(1) la mer du Nord; la mer du Sud (Dor.fr., p. 266) marea nordului ${ }^{1}$; marea miezii zi (Dor.rom., II, p. $3^{\mathrm{r}}, 3^{\mathrm{v}}$ )

(2) il fiume Negro; lungo lo sponde del Negro (Buf.it., p. 419-420) rîul negru; pe lîngă apa Negrului (Buf.rom., p. 142)

(3) tutto il paese di Terraferma (Buf. it., p. 443) toată țara Pămîntului Întărit (Buf.rom., p. 151)

(4) Terra nuova (Buf. it., p. 438) pămîntul nou (Buf.rom., p. 158)

(5) welche die Salzinsel heist (Cam.germ., p. 176) care se chiamă ostrovul de sare (Cam.rom., p. 112)

(6) les isles du cap Verd (Dor.fr., p. 10) ostroavele Capului Verde (Dor.rom., I, $4^{\mathrm{r}}$ )

(7) bis zu den Inseln des grünen Vorgebirges (Cam.germ., p. 175) pînă la ostrovele Muntelui cel verde (Cam.rom., p. 111)

(8) dem grünen Vorgebirge gegen über (Cam.germ., p. 176) împotriva Muntelui verde (Cam.rom., p. 111)

(9) die Küste de la Orejas (die Obren-Küste) (Cam.germ., p. 230) țărmurile urechilor (Cam.rom., p. 152)

Alteori, sintagme denominative total transparente și a căror semnificație etimologică (cea a apelativelor în funcție toponimică) păstrează intact raportul de desemnare implicit în denominările de tip descriptiv (formate, în principiu dintr-un determinat și un adjectiv), așa cum sînt exemplele de mai jos, nu sînt traduse, ci sînt transliterate sau transcrise fonetic:

\footnotetext{
${ }^{1}$ În toate citatele s-a păstrat ortografia din textul chirilic original, inclusiv scrierea cu minusculă a numelor proprii, acolo unde apare.
} 
(10) il s’avança dans une province, à laquelle il donna le nom de Puerto-viejo (Dor.fr., p. 305) s-au înaintat într-o provinție, căriia i-au dat nume puerto-veio (Dor. rom., II, p. $31^{\mathrm{v}}$ )

(11) Ces capitainies sont Para, Maranon-Ciaera, Rio-grande, Paraiba, Tamaraca, Fernambuc, Serégipé, Bahia, Ilheos, Spiritu-sancto, Porto-séguro, Rio de Janéiro (Dor.fr., p. 384)

Căpităniile sînt acestea: Para, maranon-chiera, rio-Grande, paraiba, tamaraca, fernambuc, sereghipe, baia, ileos, Spiritu-Sancto, Porto-Securo, rio-deianeiro (Dor.rom., II, p. 88 ${ }^{\text {r }}$ )

Păstrarea acestui tip de toponime cît mai aproape de forma originară (prin transliterare sau transcriere fonetică) nu numai că oferă indicii în privința spațiului de proveniență, ci și anulează posibila omonimie cu toponime din limba țintă. Debus (2012, p. 51), referindu-se la numele de persoană, consideră că identificarea denominatului este strict legată de forma originară a numelui şi că traducerea ar avea un efect contrar: „Die Identiflkation der Namenträger (s.a.) ist hier strikt an die originären Formen gebunden, die Übersetzung käme einer volligen Verfremdung gleich”. Tot el observă că, deși numele traductibile se traduceau în trecut, astăzi, de obicei, nu se traduc, iar acestă abordare a devenit aproape o normă. În cazul toponimelor traductibile este necesară o diferențiere între cele de tipul exemplelor (1-9), adică cele în care există o corespondență între semnificația etimologică a numelui și denominat (toponime descriptive transparente semantic), și cele în care raportul de desemnare nu se bazează pe această corespondență, cum ar fi, spre exemplu, toponimele metaforice din exemplul (11): Spiritu-sancto, transliterat Spiritu-Sancto, şi Rio de Janéiro, transcris fonetic rio-deianeiro sau ca în exemplul de mai jos:

(12) d'établir une colonie de calviniste à Rio-Janeiro (Dor.fr., p. 384) ca să întemeieză o colonie de calvini la rio-Ianeiro (Dor.rom., II, p. $87^{\mathrm{v}}$ )

Traducerea toponimelor transparente a căror semnificație etimologică nu corespunde denominatului (adică a căror motivație în actul denominativ nu a fost descrierea referentului devenit denominat) ar putea conduce foarte ușor la inferențe (etimologice, legate în primul rînd de motivația denominării) care nu corespund funcției de bază a numelui propriu, identificarea.

Surprinzătoare este netraducerea unor nume care, conform normei actuale, se traduc, probabil, în orice limbă cu o terminologie geografică minimă:

(13) zwischen der Nord- und Ostsee (Rum.germ., p. 82) dintră Nord și Ostsee (Rum.rom., p. 72)

(14) oder bis nach dem Südpol hinlaufe (Cam.germ., p. 13) ori că ajunge pînă la Zidpol (Cam.rom., p. 103).

Toponimele traductibile sînt uneori traduse, alteori traduse parțial, alteori substituite cu o variantă dintr-o limbă terță. Un exemplu relevant în acest sens este cazul toponimului Capul Bunei Speranțe:

(15) et dès-lors le cap des Tempêtes reçut le nom de cap de Bonne-espérance (Dor.fr., p. 11) și de atuncea capul tampetii au luat nume de cap de bon esperansu, care va să zică Cap de bună nădejde (Dor. rom., I, p. $4^{\mathrm{v}}$ )

(16) e poi il capo di Buona Speranza (Buf. it., p. 413) apoi capul de bună nădăjduire (Buf.rom., p. 137)

(17) il capo di Buona Speranza (Buf. it., p. 422) capul de buna speranță (Buf.rom., p. 145)

(18) um das Vorgebirge der guten Hoffnung herum (Cam.germ., p. 12) împrejurul munților de Bona Speranza, bunei nădeajde (Cam.rom., p. 9)

(19) das Vorgebirge der guten Hofnung (Cam.germ., p. 190) muntele bunei nădejdi, Capo de bona Speranza (Cam.rom., p. 123) 
Dinu Moscal

Acest exemplu indică în mod clar abordarea nesigură a numelor proprii în ceea ce privește traducerea. Deși traducătorii optează pentru traducere, mai mult sau mai puțin exactă, indicarea numelui originar pare să aibă un aport în identificarea denominatului. Acest „liber arbitru al traducătorului” în fața numelor proprii transparente semantic este un îndiciu clar că traducerea propriu-zisă a numelor proprii nu poate îndeplini acelaşi rol ca traducerea în genere a unui text (a numelor comune).

\subsection{Traduceriparțiale}

Traducerea parțială vizează în principiu toponimele parțial traductibile, adică sintagmele toponimice constituite dintr-un nume propriu opac și un apelativ. Sintagmele parțial traductibile sînt formate fie dintr-un apelativ categorial și un nume propriu (opac semantic) sau un derivat al acestuia, de tipul Munții Carpați sau Golful Persic, fie dintr-un nume propriu (opac) și un adjectiv (Arabia Felix) sau un circumstanțial (Indiile de Vest, America de Sud).

Traducerea parțială a sintagmelor toponimice transparente, absentă în traducerile actuale, este uneori o opțiune pentru traducătorii din perioada vizată. În exemplele de mai sus, referitoare la Capul Bunei Speranțe, apare adaptarea fr. Tempêtes în capul tampetii (15), dar și o substituire prin numele dintr-o limbă terță, de exemplu: munții de Bona Speranza (18), Capo de bona Speranza (19). Corectitudinea traducerii (fr. cap 'promontoriu' > rom. munți, ca în exemplul (6), sau germ. Vorgebirge 'promontoriu' $>$ rom. munte, ca în exemplele (7) și (8), ajunsă uneori la confuzii, ca în exemplul (46): oțeanul Goronei) este o problemă de traductologie (sau, uneori, este numai legată de traducător) și nu o problemă privind traducerea numelor proprii. Traducătorii cunoșteau cu siguranță echivalentul românesc al termenilor netraduşi din sintagmă (17), însă, cel mai probabil, au recurs la ceea ce au considerat ei denumirea originară a respectivei individualităţi, care ar constitui un element cu valoare identificatoare pentru cititor.

Netraducerea elementului traductibil al unei sintagme toponimice apare în unele cazuri, ceea ce nu corespunde normei actuale. Redăm cîte două exemple pentru toponimele Indiile de Vest și Indiile de Est, unul pentru cazul direct și unul pentru cazul oblic, pentru probarea veridicității netraducerii termenului transparent:

(20) Man beschloß daher, einen Mann nach Westindien zu schikken (Cam.germ., p. 166) și hotărîră a trimite un comiseri la Vest-India (Cam.rom., p. 103)

(21) und daher auch den Nahmen de westindischen Krokodils erhalten hat. (Cam.germ., p. 83) de aceea se și numi Crocodilul Vest Indiei (Cam.rom., p. 47)

(22) ob sie nicht einen Weg zur See bis nach Ostindien finden könten (Cam.germ., p. 11) nu cumva vor afla pre mare vrun drum cătră Ost-India (Cam.rom., p. 9)

(23) welches sich die handlung nach Ostindien zugeeignet hatte (Cam.germ., p. 14) carii numai loruși întrebuința neguțătoria Ost-Indiei (Cam.rom., p. 11)

Trebuie accentuat că netraducerea este strict opțiunea traducătorului, fapt probat prin glosarea dată de autor în același text:

(24) Das eigentliche Indien hingegen, zu welchem man nach Osten hin reisete, ward von dieser Zeit an Ostindien genant (Cam.germ., p. 130)

Și cealaltă India, Ost-India, adecă India răsăritului, căci spre răsărit se află (Cam.rom., p. 76)

(25) so gab man ihnen [...] den Nahmen Westindien, weil man, um von Europa aus dahin zu kommen, gegen Westen fahren muß (Cam.germ., p. 130)

dădu ei nume de Vest-India, adecă India apusului, căci de la Europa a merge într-acolo, cătră apus caută să meargă (Cam.rom., p. 76)

La nivel general predomină totuşi traducerea elementului transparent, fie că se află în poziție de determinat (apelativ ce poartă informaţia categorială), fie că se află în poziție de determinant (adjectival sau circumstanțial). Terminologia geografică, morfemele și structurile morfologice specifice epocii, adaptările 
termenilor geografici împrumutați (ost, vest, zid, see), alături de cele ale elementului opac al sintagmei denominative, sînt mărci ce constituie o amprentă a epocii în astfel de cazuri. Deși obiectivul urmărit este doar traducerea, nu și traducătorul, ceea ar implica adăugarea unui al doilea nivel de analiză, cele cîteva exemple sînt ordonate întîi în funcție de textele traduse și apoi, pe cît posibil, urmărind o grupare pe toponime:

(26) cette partie la plus considérable de l'Amérique méridionale (Dor.fr., p. 264) cea mai mare parte a americăi despre miazăzi (Dor.rom., I, p. 2)

(27) dans son livre des nouvelles découvertes dans l'Amérique septentrionale (Dor.fr., p. 407) o carte a sa care să numește noaole Descoperiri a americăi dispre miază noapte (Dor.rom., II, p. $102^{\mathrm{r}}$ )

(28) dans son histoire de l'Amérique septentrionale (Dor.fr., p. 409) în istorie sa pentru america mezii nopți (Dor.rom., II, p. 103 ${ }^{\mathrm{v}}$ )

(29) les ridicules opinions des sauvages de l'Amérique septentrionale (Dor.fr., p. 411) vrednicile de rîs socotele a sălbatecilor americăi despre miază noapte (Dor. rom., II, p. 105 ${ }^{\mathrm{r}}$ )

(30) jusqu'au golfe Persique (Dor.fr., p. 12) pănă la boazulpersesc [glosă marginală, marcată cu două linii paralele orizontale pe boazul: sinul mării de la persia] (Dor.rom., I, p. $5^{\text {r }}$ )

(31) le golfe persique (Mil.fr., p. 2 [Indice de nume proprii]) Golful Persicesc (Mil.rom., p. III [Indice de nume proprii])

(32) C'est le golfe de Venise (Mil.fr., p. 1 [Indice de nume proprii]) aceasta iaste Golful Veneții, adecă sinul mării al Veneții (Mil.rom., p. I [Indice de nume proprii])

(33) dicesi il Golfo di Venezia (Buf.it., p. 449) să chiamă colful de vineție (Buf.rom., p. 168)

(34) nel Golfo Persico (Buf. it., p. 388) în colful persianului (Buf.rom., p. 33)

(35) situata al Mezzodì del Golfo del Messico (Buf.it., p. 434) este despre amiazăzi de colful Mesicu (Buf.rom., p. 152)

(36) die da in dem grossen mexikanischen Meerbusen liegen. (Cam.germ., p. 130) care sînt în Golful de mare México (Cam.rom., p. 77)

În afară de particularitățile lexicale (miazăzi, miază noapte, sîn, boaz) și cele morfologie (-ie, -icesc, dar și -esc în cazuri care nu mai corespund normei actuale, așa cum este persesc, sau structuri ce reflectă normele limbii din perioada respectivă: dispre miază noapte, sinul mării al, Golful de mare), trebuie remarcată influența limbii sursă în calcurile colful de vineție < it. Golfo di Venezia (33) și Golful de mare < germ. Meerbuse 'golf' (36).

O situație specială întîlnim în traducerea textului lui Catiforo, unde oiconimul $\Pi \varepsilon \tau \rho o v ́ \pi 0 \lambda$ ıৎ este tradus parțial, traducătorul alegînd să traducă elementul transparent din compus și chiar să despartă compusul, pentru a indica substratul etimologic, o posibilă influență avînd și explicaţia etimologică din text:



Petru Burgu, adecă cetatea lui Petru (Cat.rom., p. 65 ${ }^{\mathrm{r}}$ )

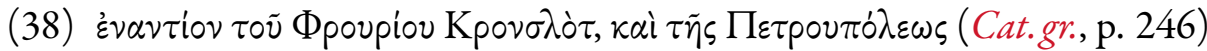
împrotiva cetății Cronslot și a petre burgului (Cat.rom., p. 87v)

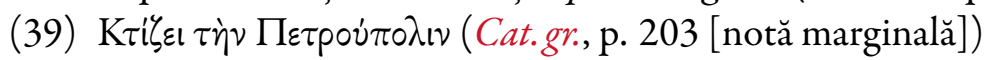
Zideaște Petru Burgul (Cat.rom., p. $65^{\mathrm{r}}$ [notă marginală, cu roșu])


la cetatea lui Petru (Cat.rom., p. $75^{\mathrm{r}}$ ) 
Soluția „explicativă” alternează cu adaptarea formei grecești, Petropolis (Cat.rom., p. 74 ${ }^{\mathrm{r}}$ ), cu preluarea adaptării formale în grecește a corespondentului german, Petruburg (Cat.rom., p. 74 ${ }^{\mathrm{r}}$ ) sau cu o formă adaptată a corespondentului german, Peterspurg (Cat.rom., p. 96 $\left.{ }^{v}\right)<$ germ. Petersburg.

Desigur, multe dintre traducerile parțiale corespund normei actuale, doar adaptarea numelui opac făcînd adesea notă discordantă:

(41) a Levante del fume Gange (Buf.it., p. 391)

despre răsărit de rîul Gangul (Buf.rom., p. 38)

(42) in dem Tejostrome hinauf (Cam.germ., p. 121) pre rîul Teio în sus (Cam.rom., p. 70)

(43) gegen Morgen den Fluß Indus (Mil.germ., p. 101) cătră răsărit rîul Indus (Mil.rom., p. 134)

Un fenomen ce poate fi luat în considerare în cadrul traducerii parțiale este adăugarea termenului ce indică categoria onomastică, pentru a facilita înțelegerea textului de către cititor. Chiar dacă termenul ca atare nu apare în textul sursă, traducătorii apelează la această specificare îndeosebi pentru toponimele mai puțin cunoscute:

(44) aufdem Ufer der Wilia (Rum.germ., p. 57)

la țărmurile rîului Vilia (Rum.rom., p. 54)

(45) poi sul Gange (Buf.it., p. 393) asupra rîului Gangul (Buf.rom., 40)

(46) Aquitaine étoit située entre l'Océan, la Garonne \& les Pyrénées (Mil.fr., p. 11) Acvitania, între oțeanul Goronei și între Muntele Pirenei (Mil.rom., p. VII [Indice de nume proprii])

Termenul geografic ocean din „oțeanul Goronei”, pentru „la Garonne” (46)-fluviu pentru care avem astăzi atît Fluviul Garonne (după fr. Garonne), cît și Fluviul Garona (după sp. Garona)—este în mod evident complet inadecvat. Acest aspect nu poate fi luat în considerare la nivelul analizei traducerii numelor proprii, deoarece este vorba despre înțelegerea greșită a textului, nu despre o opțiune de traducere.

\section{Concluzii}

Cercetarea traducerii propriu-zise a toponimelor într-un moment în care multe dintre acestea nu aveau încă un echivalent în limba română are o dublă importanță. Pe de o parte, se identifică funcționalitatea semantică a termenilor geografici, precum și diferențele dintre primele intrări în limba română a unor toponime, inclusiv oscilarea între mai multe posibilități, și toponimele echivalente actuale. Pe de altă parte, opțiunile diferite de traducere ale aceluiași traducător sau între traducători și, în special, diferențele față de variantele care au ajuns să fie normate astăzi (la nivel de limbă, nu numaidecît și oficial) constituie o bază pentru abordarea teoretică a numelui propriu. Aceste diferențe sînt argumente pentru demonstrarea nonfuncționalității semnificației etimologice a numelor proprii (semnificația lexicală a etimonului). Faptul că într-o limbă se impune o traducere sau o adaptare formală a unui toponim traductibil sau parțial traductibil se datorează într-o oarecare măsură și tradiției, însă opțiunea de a le traduce sau nu este și rezultatul tipului toponimului (în principiu, sintagme toponimice). 


\section{Bibliografie}

\section{A. Lucrări de referință}

Algeo, J. (1973). On Defining the Proper Name, University of Florida Press, Gainesville.

Ballard, M. (2011 [2001]). Numele proprii în traducere, traducere, cuvînt înainte și note de Georgiana Lungu-Badea, Editura Universității de Vest, Timișoara.

Clarinval, B. (1967). Essai sur le statut linguistique du nom propre, în „Cahiers de lexicologie”, 11, p. 29-44, Crossref.

Debus, F. (2012). Namenkunde und Namengeschichte. Eine Einführung, Erich Schmidt Verlag, Berlin.

Gardiner, A. (1957 [1940]). The Theory of Proper Names. A Controversial Essay, Oxford University Press, London.

Gînsac, A.-M. et al. (2017). Practici de traducere a numelor proprii în scrisul românesc premodern (1780-1830), Editura Universității „Alexandru Ioan Cuza”, Iași.

Grass, T. (2002). Quoi! Vous voulez traduire «Goethe»? - Essai sur la traduction des noms propres allemand-français, Peter Lang, Berne.

Hjelmslev, L. (1971). La nature du pronom, în Essais linguistiques, Minuit, Paris, p. 201-207.

Kleiber, G. (1981). Problèmes de référence: descriptions définies et noms propres, Centre d'Analyse Syntaxique, Metz.

Kuryłowicz, J. (1980). The Linguistic Status of Proper Nouns (Names), în „Onomastica”, 25, p. 5-10.

Malblanc (1968 [1944]). Stylistique comparée du français et de l'allemand, Henri Didier, Paris.

Mańczak, W. (1968). Nom propre et nom commun, în „Revue Internationale d'Onomastique”, 20, p. 205-218.

Molino, J. (1982). Le nom propre dans la langue, în „Langages”, 66, p. 5-20, Crossref.

Moya, V. (2001). La traducción de los nombres propios, Cátedra, Madrid.

Vaxelaire, J. L. (2005). Les noms propres. Une analyse lexicologique et historique, Honoré Champion, Paris.

Vaxelaire, J. L. (2006). Pistes pour une nouvelle approche de la traduction automatique des noms propres, în „Meta”, 51 (4), p. 717738, Crossref.

Vinay, J.-P. \& Darbelnet, J. (1958). Stylistique comparée du français et de l’anglais, Didier, Paris.

\section{B. Surse}

Buf. it. $=$ [Claude Buffier], Geografia universale del $\mathrm{P}<$ adre $>$ Buffier, Edizione prima Romana aumentata, corretta e ridotta in miglior forma, con un nuovo Trattato della Sfera e d'una Dissertazione sopra l'origine e progresso della Geografia, dal $\mathrm{P}<$ adre> Francesco Jacquier, in Roma, a spese di Venanzio Monaldini, mercante di Libri, 1775.

Buf.rom. $=$ [Claude Buffier], De obște gheográfie pe limba moldovenească, scoasă de pe Geográfie lui Búfiér după orînduiala care acum mai pre urmă s-au aşăzat în Académie de la Parízi, acum întîi tipăită în zilele Prealuminatului și Preaînălțatului Domnului nostru Alexandru Ioan Calimah $\mathrm{V}<$ oie > vod, cu blagosloveniia și cu toată cheltuiala Preaosfințitului Mitropolit a toată Moldáviia, Kirío Kir Iácov, întru a Preosfinției sale Tipográfie, s-au tipărit de ierodiacon Gherásim și de Pável Petrov tipografi), în $S f<\hat{i}>$ nta Mitropolie în Iaşi, avgust 22, 1795.

Cam.germ. = [Joachim Heinrich Campe], Kolumbus oder die Entdekkung von Westindien. Ein angenehmes und nützliches Lesebuch für Kinder und junge Leute, von J.H. Campe, mit allerhochst gnädigst Kayserl. Privilegio, Tübingen, bey Wilh. Heinr. Schramm und Joh. Friedr. Balz., 1782.

Cam.rom. = [Joachim Heinrich Campe], Descoperirea Américii. O carte foarte folositoare, alcătuită de Ioánn Háinrih Cámpe, acum întîiu de un iubitoriu de neamul românesc pre românie tălmăcită și dată afară la lumină, tomul I, cu 4 figuri, cu toată chieltuiala lui Nicóla Nicoláu din Brașov, dată în tipariu la Buda, Crăiasca Tipografie a Universitatei din Péșta, 1816.

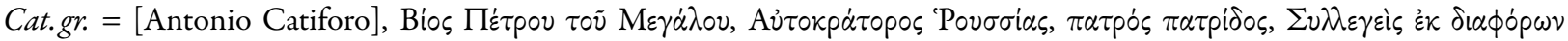

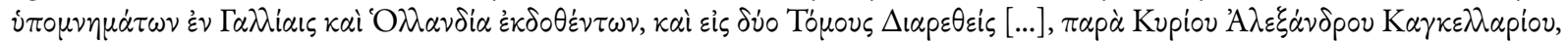

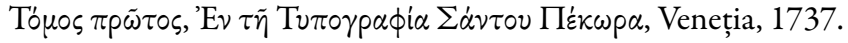

Cat.rom. $=$ [Antonio Catiforo], Istoria rușilor și viața Marelui Petru, monarhul rușilor, Brașov, traducere efectuată înainte de 1783, copie de Zamfir Marco, din 1788 [în ms. rom. 3161, BAR, p. 1-186].

Dor.fr. = [André Guillaume Contant d'Orville], Histoire des différents peuples du monde, contenant les cérémonies religieuses et civiles, l'origine des religions, leurs Sectes \& Superstitions, \& les Mours \& Usages de chaque Nation, dédiée à monseigneur le Duc de Vrilliere, ministre et secrétaire d'état par M. Contant Dorville, tome cinquième, à Paris, chez Herissant le Fils Libraire, 1771.

Dor. rom. $=$ [André Guillaume Contant d'Orville], Istoría Americăi, cuprinzind un perilipsis a aflării ei, țerimóniile bisericești și politicești [...], acum întîi tălmăcite în dialectul moldovenesc, prin ostineala smeritului Gherasim, arhimandrit Mitropoliei Iașului, Iaşi, tomul I (1800), tomul 2 (1795) [în ms. rom. IV-17, BCU-Iaşi].

Mil.fr. = [Claude François Xavier Millot], Éléments d'histoire générale, première partie: Histoire ancienne, par M. l'Abbé Millot de l'Académie Françoise, \& des Académies de Lyon \& Nancy, tome premier, Nouvelle édition augumentée, à Paris, Chez Durand neveu, 1790.

Mil.germ. $=$ [Claude François Xavier Millot], Des Herrn Abt <Claude> Millot, Mitglieds der Akademie zu Lyon, Universalhistorie alter, mittler und neuer Zeiten, aus dem Französischen, mit den Zusätzen von Wilhelm Ernst Christiani, königlich 
Dänischen wirklichen Justiz - Rath und ordentlichen Professor der Weltweisheit, Beredtsamkeit und Geschichte, wie auch Bibliothekar der königlichen Universität zu Kiel, Erster Band, Bey Franz Haas Buchhändler, Wien, 1794.

Mil.rom. = [Claude Millot], Istorie universală, ádecă de obște, care cuprinde în sine întîmplările veacurilor vechi, întocmită prin signior Mílot, commembru Académii Frîncești din Lyon, iară acum întîia dată tălmăcită în limba românească, tomul I, în Búda s-au tipărit, în Crăiasca Tipografie Orientalicească a Universitatei Péștii, 1800.

Rum.germ. $=$ [Johann Daniel Friedrich Rumpf], Alexander I, Kaiser von Russland. Ein Regierungs-und Karaktergemälde, von I.D.F. Rumpf, Königl. Preuss. expedir. Secretär bei der Abgaben-Direction in Berlin, bei G. Hayn, mit dem Bildniss des Kaisers, 1814.

Rum.rom. = [Johann Daniel Friedrich Rumpf], Arătarea stăpînirei și a caracterului lui Alexándru I, împăratul a toată Róssia, întocmită prin I.D.F. Rumpf, Crăiescul Praisesc a Direcției din Berlin Secretar-Expedítor și Mărirei Sale celui pre dreptate și moștenitoriu Craiu al Borúsiei Frídrih Vílhelm III închinată, iară acum întîiu pre Românie prefăcută și tipărită la Buda, în Crăiasca Tipografie a Universitatei Ungáriei, 1815. 